\title{
Strengthen the Application Ability Cultivation - Financial Management Teaching Reform Study
}

\author{
Minhuan Gong ${ }^{1, \text { a }}$ \\ ${ }^{1}$ Shaanxi Institute of International Trade \& Commerce, Xi'an, Shaanxi, China, 712046 \\ aemail,
}

Keywords: Application Ability, Cultivation, Financial Management, Teaching Reform

\begin{abstract}
As one of professional financial management core courses in finance and economics, is an application-oriented discipline. Traditional teaching methods to teach too much emphasis on theoretical knowledge and ignored the students' applied ability. According to the characteristics of students to improve existing teaching mode drawbacks to explore how the original teaching methods of financial management reform and innovation, strengthen students' applied ability training to foster independent analytical skills, creative thinking that is the hallmark of teaching development.
\end{abstract}

\section{Introduction}

As China's market economic system reform, and the extent of foreign economic cooperation has been strengthened, so that domestic enterprises are constantly improve the management system, thereby forcing companies facing increasingly fierce competition. Financial management is the core issue of corporate governance is the access to and effective use of the management of the funds concerned. The success of financial management is an important issue related to the survival and development. Effective financial management is necessary to ensure the normal operation of the enterprise. In 2007, China promulgated the "enterprise financial rules" of Enterprise Financial Management macro and micro for an effective system to define, is the first time more thoroughly, according to the requirements of the market economy, the financial management system of reconstruction. This fully shows that the Government attaches to corporate financial management. However, to improve financial management, it is necessary to have a high-quality master financial management theories, methods and skills, with modern financial concepts and financial management capacity of financial management. 2008 outbreak of the global financial crisis, so that people of modern financial management concepts and financial management capabilities have a more profound understanding. For application oriented talents to cultivate higher vocational education, how to graduate to the society with modern financial concepts and financial management capacity is urgently needed to resolve urgent problems.

\section{The Status of Financial Management Teaching}

China's traditional financial management teaching method is mainly theoretical teaching focus, more emphasis on the teaching of financial management theory and knowledge, ignored the students' applied ability. Through my teaching practice that the traditional mode of teaching primarily in the following aspects of the drawbacks:

Teaching Content is Unreasonable. Financial Management and economics, accounting, statistics and management science and other disciplines of knowledge associated, so the actual teaching process will often repeat the teaching content, teaching resources waste phenomenon. Setting unreasonable financial management of the existing teaching content is not conducive to the students to acquire new knowledge.

The Students' Enthusiasm is Not High. In general, vocational education training object, the main image having a relatively strong thinking, abstract thinking and features relatively weak. Image Thinking strong man, can quickly get empirical knowledge and strategic, and for declarative theoretical knowledge is relatively exclusive. Most of the traditional teaching financial management 
to the teachers teach mainly unilateral. As the two sides lack of effective interaction, students usually learn in a passive position, lack of initiative thinking space, so learning enthusiasm is not high, the classroom atmosphere is boring.

The Student's Practical Ability is Poor. Due to the financial management course certain financial concepts more abstract, plus some financial problems and more corporate data, calculated financial functions are more complex, to the students fully understand the knowledge of financial management caused considerable difficulties. And traditional classroom teaching methods do not provide the necessary training for students to analyze and solve financial problems of capacity, easily lead to students' practical ability is poor.

\section{The Necessity of Financial Management Teaching Reform}

The purpose of teaching financial management course is to train students theoretical knowledge and financial management skills to enable them to work in enterprises and institutions engaged in related fiscal authorities, banks and other financial institutions. Through the investigation and the demand for talent in recent years, China's enterprises, banks and other related industries forecast found that units generally need is skilled with practical skills and analytical problem solving financial management personnel, including accounting, investment evaluation, financing management, risk prevention and other comprehensive vocational skills.

Accordingly, the financial management of the application as a very strong discipline, should be to train business people in related industries frontline play its due role. However, in the current financial management of the teaching process, teachers basically unilateral acts led, student usually passive recipients of information and knowledge, not easy to form a systematic and coherent way of thinking, there is too much of students to teachers dependence, lack of self-learning ability and flexible use of capacity, resulting in students' ability weak, lack of innovation, into the community after graduation, can not meet the job requirements. Therefore, demand-oriented vocational teaching reform, strengthen the relevance and application of the curriculum, to train high-quality talents as the goal has become a necessity.

\section{The Construction of Financial Management Teaching Reform Program}

Foster an innovative spirit and ability of financial management talent is the basic requirement of building an innovative financial officer. "Innovation" is fundamental in practice. In 2007 the Ministry of Education No. 1 and Document 2, with particular emphasis on Practice Teaching and reform and innovative training model, and to carry out the practice base construction, broadening school practice channels; to implement Students creative experimentation program, Promoting University in the teaching content, curriculum comprehensive reform of the system, practical aspects and other aspects; to advocate heuristic teaching and research as the core of learning, to explore new teaching ideas, training mode and management mechanism. These requirements are for us to build a scientific system of teaching pointed out the direction. Reform of Financial Management Course to build a scientific teaching mode, can be considered from the following aspects:

Optimize the Course Structure and Adjust the Teaching Content. Reform of teaching content and course structure is a major foothold Training Mode, job requirements analysis should start from the actual work required professional competence and knowledge of literacy, taking the "Apply" as the theme and features to optimize the course structure, teaching adjustment content.

Financial Management application of culture, the need for comprehensive application of knowledge, innovation and play. Reasonable Construction Curriculum Group, to make public basic courses, specialized basic courses, specialized courses, and cultural quality of lessons, classes, and other practical skills curriculum modules constitute a complete curriculum, form the basis of students' practical abilities. In the curriculum, not only to pursue systematic and integrity disciplines, but also based on the ability of the training objectives and requirements of modern enterprise financial management positions demand, screening and training of application ability disciplines 
directly related professional knowledge content, in order to form a innovative comprehensive ability as the main highlight of the basic skills and application system for curriculum purposes.

Under the premise to ensure systematic subject knowledge, requiring teachers to classroom teachings cull succinctly, not scripted, it is necessary to avoid duplication of content between courses, but also to ensure the course content between the front and rear coherence. In addition, teachers should provide students with teaching aids, arranged after-school reading stories, important articles and bibliographies and Hot Articles on newspapers and magazines, with emphasis on basic theory to analyze the latest developments, to digest the textbook knowledge and practice combine up, and to break through the limitations of textbooks lag, so the pace of development in keeping with the era of classroom teaching. Meanwhile, a large number of extracurricular reading, imperceptibly improve students' learning ability, the ability of abstraction to simplify, synthesize the ability and judgment to create the necessary conditions for future development.

The Introduction of Modern Educational Technology and Change Teaching Methods. Due to the limitations of corporate financial data confidentiality and office locations, practical teaching by the funds, base and other restrictions, the more difficult to implement, the effect is difficult to guarantee; the traditional "blackboard + chalk" teaching methods difficult to achieve good teaching . The introduction of high-tech modern teaching methods, the use of multimedia teaching methods can make up for this shortcoming. In the teaching process interspersed with projection, slides, CD-ROM, CAI and other auxiliary teaching methods, improve teaching intuitive and dynamic, and can be focused to help students understand the concepts and to master methods. And because the graphics and audio-visual Mao, allow to reflect the concepts and processes, multi-angle to mobilize the students' emotion, attention and interest, helping to overcome the teaching difficulties. At the same time, due to the large amount of information, mass resistance, both to improve teaching efficiency, but also to stimulate the students 'interest in learning, expanding students' knowledge.

To Strengthen Financial Management Case Teaching. Case teaching as a practical, participatory strong classroom teaching in each subject teaching has been widely used. For financial management case teaching, since the class is limited, pay special attention to case selection and design, design and analysis to be the case for some important financial theory, targeted teaching. Classroom teachers in the context of Enlightenment theory of teaching, through the case about and commented on the location of the student business people on to provide students with an understanding and problem-solving simulated combat an opportunity of viewing the case as a protagonist the financial management environment for students to learn the knowledge of financial management theory applied to the financial case to inspire students to recognize their own potential, enhance self-confidence and foster innovation.

Conduct Computerized Financial Management. Training emphasizes teaching students practical ability and creative spirit of today, experiment and training teaching theory with practice as an important part of practice, its importance is self-evident. With the development of information technology, a large number of accounting software, management software, one after another, and can be widely used, these software are more or less related to the content of financial management, but also can not be achieved for a particular financial model, and to Microsoft Excel spreadsheet software on behalf of its simple and convenient dynamic links, graphics production, graphics and other tools can be adjusted easily and intuitively build model to solve various financial management issues, with strong operability. Therefore, the financial management practice teaching, should carry out computerized financial management training teaching, relying on computer labs, use a versatile teaching environment, financial management Excel application as the main content of teaching, guiding students in a common, simple Excel tool to create each kinds of financial management case calculation model, financial analysis and decision making. Professional teachers and key substantive content of the training program involved in the process to give general guidance, and the results are given comprehensive training reviews.

Organize Trust Financing According to Local Conditions. Students with a basic analysis of the financial problem solving skills and practical ability, the number of teachers in a timely manner to carry out comprehensive research topics, with emphasis on cultivating students' comprehensive 
quality. From the nature of the financial management course, the topic can be set up value of the company management as the main line, respectively, from a financial situation analysis, financial forecasting and planning, long-term value of the company's evaluation of three aspects of the design, so that students in small groups from different angle of collaboration research project. The entire case study process student-led teachers to guide the actors involved, the students according to the basic objectives of the study, combined with the sample characteristics of the company, the independent decision of the relevant data needed, methods, specific research questions and identify research programs, so, to provide students with more space to dig the company's depth of information and analysis, can effectively improve students' self-learning ability. In addition, each thematic studies students through group collaboration in the completion of research topics but also to enable students to be more comprehensive and more firmly mastered the basic theory courses, principles and methods of its practical operation and application, imperceptibly improve the ability to discriminate and thinking ability independent learning, students develop the courage to face the problem, innovative overall quality.

Strengthen Campus Practice Teaching Efforts. Financial management practice teaching, in addition to the use of school resources, we must also actively expand channels for school practice, strengthen the close cooperation of research. On the one hand, to carry out production and education cooperation, make full use of domestic and foreign resources, expanding inter-school, school-enterprise cooperation, between the school, by contacting the practitioners of outstanding people, on-site seminars, online video and other forms of their participation teaching, strengthen students' perceptions on the financial practice; on the other hand, strengthen the construction of practice bases, and society, as well as enterprises and institutions to build the industry practice base, to internships, to help post internships, etc., so that students can be allowed within the range as much as possible contact with the real business, with job experience, improve the ability to solve practical problems, to develop students practical skills.

\section{Conclusion}

In summary, the implementation of teaching practices to promote the application of innovation ability cultivation of students from the external environment and internal mechanism. In addition, the part of the practical results as part of the student's thesis, allowing students to graduate early completion of the design aspects of teaching practice, solves the contradiction between graduation and employment. Meanwhile, the teachers, the practice can be incorporated into the results achieved in the classroom to enrich the content of classroom teaching, stimulate students' enthusiasm for innovation practice, improve their professional qualities.

\section{Acknowledgements}

Fund Project: Shaanxi Private Colleges Teaching Method Reform Research Based on the Applied Technology Ability Cultivation;

Shaanxi Province Education Science "Twelfth Five-Year Plan" in 2014 Research Topic.

\section{References}

[1] Li Jingyuan. Finance Teaching and Research, Vol. 6 (2004) No 53, p.25-26

[2] Wang Yunhui, Wang Qunyong. Teaching and Management, Vol. 12 (2005) No 27, p.74-76

[3] Jing Jianfen, Hou XuSiem. Theoretical Discussion, Vol. 30 (2004) No 19, p.144-145

[4] Qin Yule. Teaching and Management, Vol. 29 (2008) No 27, p.21-23

[5] Gu Xiaocun, Sun Jing. New Quality Management, Vol. 8 (2003) No 27, p.57-60 